\title{
ТЕХНОЛОГІЧНЕ ЗАБЕЗПЕЧЕННЯ ЕКСПЛУАТАЦІЙНИХ ВЛАСТИВОСТЕЙ ПОЛІГРАФІЧНОГО ОБЛАДНАННЯ НА ОСНОВІ СИСТЕМИ КОНТРОЛЮ
}

๔ А. В. Несхозієвський, к.т.н., ст. викладач, НТУУ «КПІ”, Київ, Україна

В статье рассматривается комплекс технологического обеспечения эксплуатационных свойств полиграфического оборудования на основе системы контроля производства, в результате внедрения которого повышается качество полиграфической продукции и обеспечиваются необходимые показатели надежности техники.

\section{A complex of technological support of working characteristics} in printing equipment is offered. It is based on the production control system, and helps to increase quality of printing products and needed parameters of machine's reliability.

\section{Постановка проблеми}

Збільшення вимог до якості поліграфічної продукції стало одною з основних причин швидкої модернізації поліграфічного обладнання, в тому числі - у вітчизняних друкарнях. За останні 10-15 років суттєво збільшилися можливості автоматизації технологічних операцій та процесів, швидкість друку аркушевих (до 18 тис. відб./год.) та рулонних (до 90 тис. прим./год.) офсетних машин, було запроваджено нові можливості друку та оздоблення в режимі in-line.

Проте швидкі темпи розвитку поліграфічної промисловості не завжди пов'язані з максимальною інтенсифікацією виробництва. Швидкості роботи друкарського обладнання часто $€$ меншими за нормативні, а якість друкованої продукції ще не повністю відповідає вимогам стандартів та має великі можливості для покращення [1-3]. На підприємствах спостерігаються значні простої друкарських машин, значні відходи паперу, ОГТП та інших витратних матеріалів [4, 5]. Постає питання про створення системи комплексного технологічного забезпечення експлуатаційних властивостей поліграфічного обладнання.

Основною причиною необхідності такої системи є процеси зношування, що відбуваються в друкарському та післядрукарському обладнанні. В результаті спрацювання вузлів та деталей при друкуванні з'являються ефекти проковзування, збільшення розтискування растрових точок, погіршення суміщення фарб (до 0,8-1,1 мм і більше), зростає ризик проходження подвійних аркушів або 
розривів паперової стрічки (для аркушевих та рулонних офсетних машин відповідно), збільшуються виробничі витрати через незаплановані простої обладнання, передчасний вихід з ладу офсетних гумово-тканинних полотен, піддекельних матеріалів, збільшення коефіцієнту браку та iн.

Як наслідок, постає гостра проблема розробки прогресивних технологічних процесів та систем контролю роботи виробництва, аналізу та ретельного дослідження процесів зношування деталей поліграфічного обладнання, технологій підвищення експлуатаційних властивостей машин (інтегрованих до систем контролю).

\section{Аналіз попередніх досліджень}

Шляхом вирішення проблеми передчасного виходу з ладу механізмів може стати розробка технологічного забезпечення експлуатаційних властивостей обладнання, що дозволяла би зменшити зношування деталей за допомогою їх зміцнення та відновлення. На теперішній час існує велика кількість технологічних процесів зміцнення та відновлення деталей поліграфічного обладнання, проте ресурс таких деталей у 85 \% випадків після відновлення $€$ невисоким, а якість поліграфічної продукції - зниженою порівняно з результатами, отриманими із новими вузлами [6]. Проте існують випадки, коли ресурс деталей, що відновлені прогресивними способами, у декілька разів вищий за ресурс нових деталей [7].
Одночасно із проведенням оздоблювально-зміцнюючої обробки (далі - О3О) деталей поліграфічного обладнання логічним $€$ створення системи контролю виробництва, що завдяки раціональній експлуатації техніки та контролю виробничих факторів забезпечить збільшення ресурсу обладнання в цілому. Слід зазначити, що системи, розроблені за останні 10 років, не дають можливості повноцінно впливати на експлуатаційні властивості поліграфічного обладнання, адже контролюють лише частину виробничих показників і не враховують стан друкарського обладнання; справність різних вузлів та модулів, зношення частин, механізмів та поверхонь деталей майже не контролюються.

\section{Мета роботи}

Метою роботи стала розробка теоретико-експериментальних рішень для технологічного забезпечення експлуатаційних властивостей поліграфічного обладнання на основі нового підходу до системи контролю виробництва, що дозволить зменшити зношування деталей та підвищити якість поліграфічної продукції.

\section{Результати проведеного дослідження}

В результаті проведеного дослідження висунуто гіпотезу про наявність прямого зв'язку між виробничими факторами типом обладнання, навантаженням, кліматичними умовами на підприємстві, частотою проведення планово-попереджуваль- 
них ремонтів (ППР), та ступенем зношування деталей і, в результаті, якістю поліграфічної продукції. Створення системи контролю дозволяє управляти процесами зношування і розробити повноцінний комплекс технологічного забезпечення експлуатаційних властивостей поліграфічного обладнання, що підвищує якість поліграфічної продукції.

Для перевірки гіпотези та проаналізованих технічних рішень в ході досліджень було розроблено методику побудови математичних моделей та комплексного аналізу технологічних факторів, що дозволяє досліджувати такі складні процеси, як мікрозсуви офсетного гумовотканинного полотна та піддекель- ного матеріалу під час друкування на аркушевих та рулонних офсетних друкарських машинах, їх вплив на якість поліграфічної продукції, керувати процесами ОЗО фарбових валів друкарської машини.

В якості основного технічного рішення розроблено технологічний процес, складовими якого є ОЗО з послідовним нанесенням полімерних покриттів і чистовою обробкою фарбових валів фарбового апарату аркушевих офсетних друкарських машин.

Вперше побудовано логічну схему моделі впливу технологічних факторів на якість відтворення поліграфічної продукції. Дана схема дозволила пов'язати параметри деталей та їх обробки 3 якістю полі-

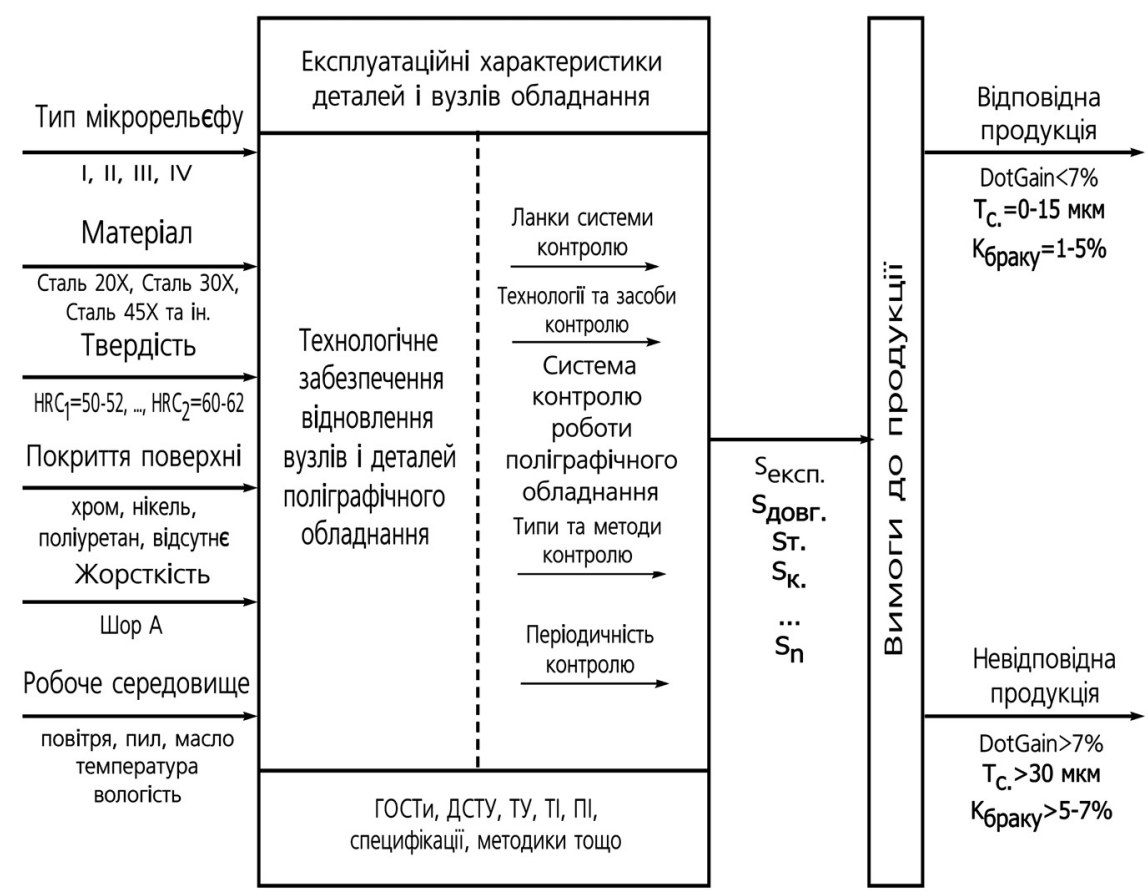

Рис. 1. Логічна схема моделі впливу технологічних факторів ОЗО на якість поліграфічної продукції 
графічної продукції, за допомогою технологічного забезпечення (рис. 1).

Вхідними даними в даному випадку є параметри: тип нанесеного мікрорельєфу (I-IV тип), матеріал деталі (Сталь 20X, Сталь 30X, Сталь 45X та ін.), твердість (HRC), наявність чи відсутність покриття поверхні, жорсткість (Shore A), робоче середовище. Управління якістю стосується як основного технологічного, так і складових виробничого процесу: підготовки матеріалів та робочих розчинів, експлуатаційних характеристик обладнання, підготовки та підтримування необхідного кваліфікаційного рівня персоналу, відповідного метрологічного забезпечення, нормативних та організаційно-розпорядчих документів.

Побудова логічної схеми дозволила створити математичну модель для розрахунку контактної площі поверхні, утвореної за допомогою повністю регулярного мікрорельєфу, для випадку утворення тетрагональної структури.

В результаті створення математичного апарату визначено контактну площу після деформації поверхні:

$$
\begin{aligned}
& S_{k}=2 \pi r l \frac{4 r}{\sqrt{3} d} \arcsin \frac{\sqrt{3} d}{4 r}- \\
& -\frac{1}{2}\left(\frac{4 r}{\sqrt{3} d}\right)^{2}\left(1-\sqrt{1-\left(\frac{\sqrt{3} d}{4 r}\right)^{2}}\right) .
\end{aligned}
$$

Розроблений математичний апарат дозволяє суттєво змен- шити кількість експериментальних випробувань, потрібних для розрахунку та виміру контактної площі поверхонь деталей, виконувати розрахунки щодо зміни площі після нанесення регулярного та повністю регулярного мікрорельєфу та підвищити точність вибору технологічних режимів обробки деталей. Крім того, за допомогою даної математичної моделі стає можливим виконувати подальші технологічні операції по відновленню деталей, а також проводити експериментальні дослідження, пов'язані із впливом контактної площі на якість поліграфічної продукції.

Створення математичної моделі дозволило розробити алгоритм на основі якого було створено технології ОЗО та підвищення експлуатаційних характеристик офсетних циліндрів i фарбових валів аркушевих офсетних друкарських машин (рис. 2).

Запропонований алгоритм та розроблені технологічні процеси дозволяють стверджувати про високу ефективність розробленого технологічного процесу. Його застосування дозволило збільшити адгезію гуми до тіла валу, підвищило зносостійкість під час друкування УФ-фарбами та дозволило скоротити періодичність планових відновлень валів у 1,6-1,9 разів. Розроблений алгоритм дозволив пов'язати параметри роботи поліграфічного обладнання, звичайні технологічні операції із режимами ОЗО.

Крім того, під час дослідження виявлено можливість підвищення експлуатаційних характе- 
ристик деталей при впровадженні системи контролю з врахуванням ОЗО із накатуванням повністю регулярного мікрорельєфу. Проаналізовано причини появи браку під час виробничої діяльності та досліджено вплив технологічного забезпечення на точність роботи машини, коефіцієнт браку, витрати ОГТП та витрати часу на проведення ППР, ТО та оглядів поліграфічного обладнання на прикладі офсетної друкарської машини (рис. 3, 4).

В середньому обладнання, що працює за III типом системи контролю та піддається О3О, зменшує коефіцієнт браку на 30 \% порівняно 3 початковим станом, до мінімального значення - 3,9 \%. Завдяки підвищенню точності роботи до 0,05-0,07 мм, та враховуючи особливості використання технологічних рішень щодо ОЗО поверхні офсетних циліндрів, скорочуються витрати ОГТП та знижується рівень розтискування.

Крім того, після впровадження у виробництво системи контролю із технологічними операціями О3О, суттєво змен-

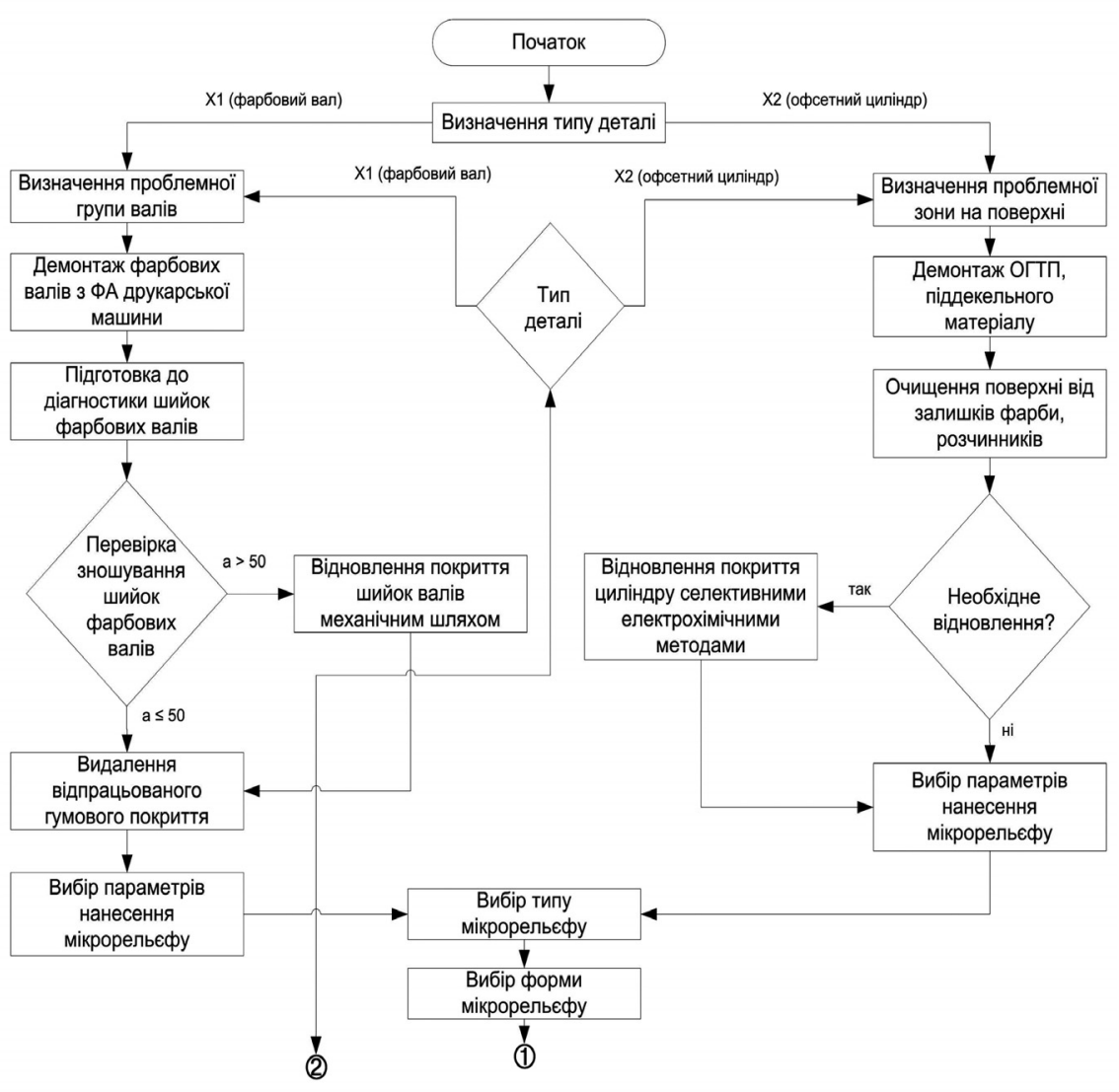

Рис. 2. Алгоритм керування технологічним процесом ОЗО фарбового валу та офсетного циліндру друкарської машини в рамках системи контролю. Початок 


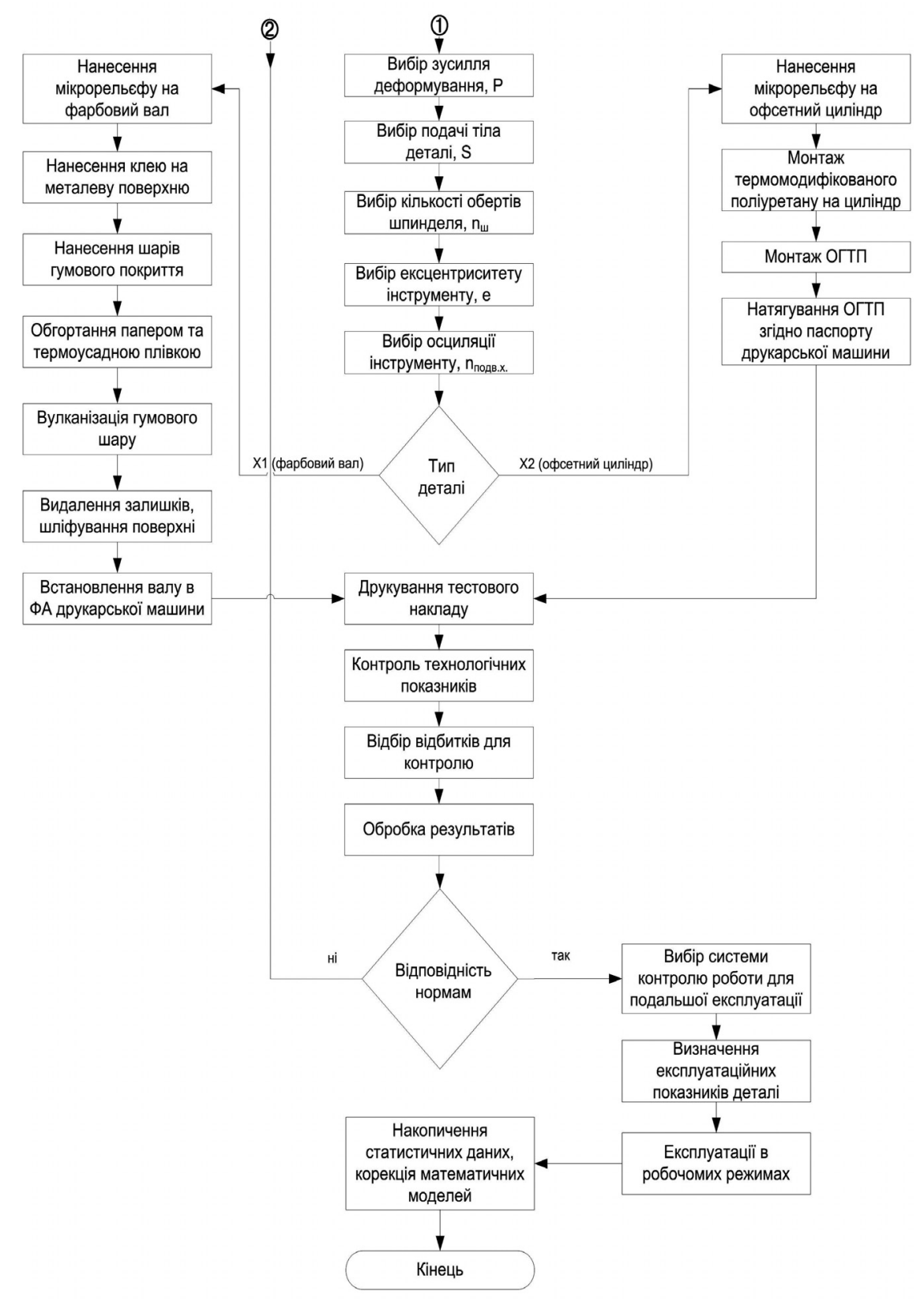

Рис. 2. Алгоритм керування технологічним процесом ОЗО фарбового валу та офсетного циліндру друкарської машини в рамках системи контролю.

Закінчення 


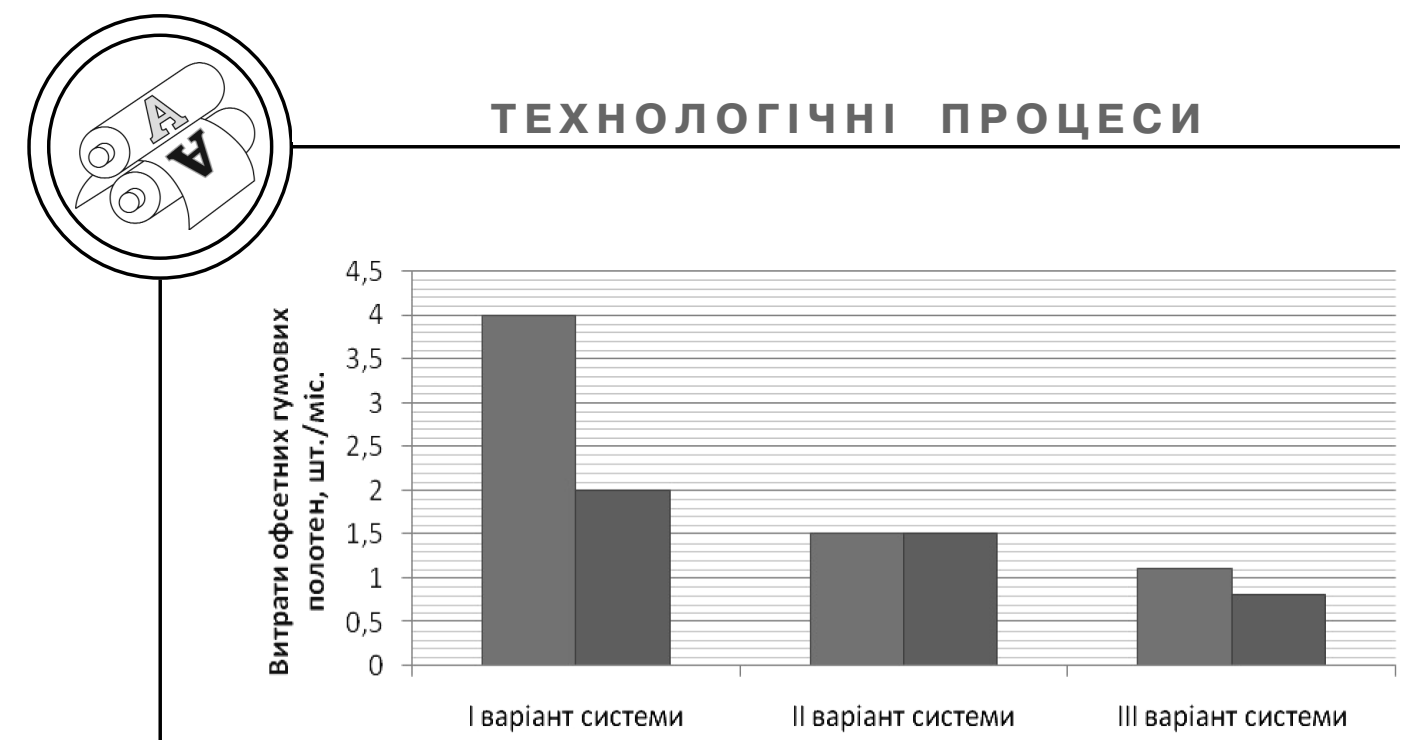

Рис. 3. Витрати ОГТП під час проведення довгострокового експерименту, до та після проведення ОЗО деталей з врахуванням наявності системи контролю

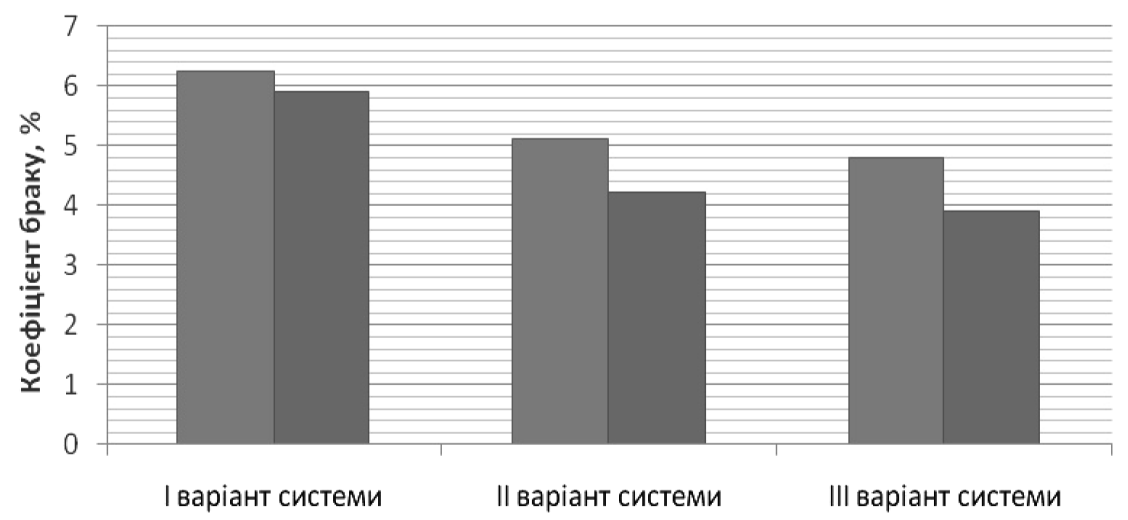

Рис. 4. Коефіцієнт браку під час проведення довгострокового експерименту, до та після проведення ОЗО деталей з врахуванням наявності системи контролю

шується час простою поліграфічного обладнання, знижуються трудові затрати на проведення ППР і ТО. Середнє скорочення після проведення відновлення складає більше $30 \%$ тільки в часі, витраченому на ППР та ТО.

У випадку появи залишкової втоми декелю досліджувалися зміни на повністю новому ОГТП та піддекелі (після друку 1000 відбитків) та старому (після друку 1000000 відбитків). Максимальна деформація декелю в обох випадках склала 0,04 мм. Час, необхідний для повного деформування та відновлення декелю, змінювався у незначних межах для нового $(1,1$ с для максимальної деформації) та старого декелю (1,0 с для максимальної деформації). Старіння найбільше спостерігалося 
в зоні відновлення товщини декелю, а саме в діапазоні 0,0-0,02 мм - час, необхідний для відновлення, збільшувався, залишкова втома збільшувалася, товщина декелю майже не змінювалась.

Після проведення ОЗО та впровадження системи контролю час, необхідний цикл деформування та відновлення, зменшився на $48 \%$, при цьому величина деформації залишилася аналогічною - 0,04 мм. Дана залежність вказує на суттєве збільшення пружності декелю, зменшенні мікрозсувів під час проходження зони друкарського контакту, та підвищенні можливостей обладнання щодо відпрацювання складних матеріалів 3 великою зміною мікрорельєфу поверхні, збільшеної товщини та ін.

\section{Висновки}

1. Встановлено, що якість поліграфічної продукції (розтискування, кольоровий зсув, суміщення та ін.) залежить від якості поверхневого шару деталей, і може бути підвищена за рахунок додаткової ОЗО вузлів та запровадження системи контролю виробництва. Це дозволило розробити і реалізувати гіпотезу про вплив виробничих факторів на процеси зношування деталей поліграфічного обладнання, та перейти до теоретичного та експериментального опрацювання запропонованої гіпотези.

2. Вперше побудовано логічну схему моделі впливу ре- жимів ОЗО на якість відтворення поліграфічної продукції, в яку інтегровано систему контролю роботи виробництва, що дозволяє не тільки контролювати процес, але й керувати виробничими і технологічними факторами, що впливають на процеси зношування фарбових валів, офсетних циліндрів та інших деталей поліграфічного обладнання.

3. Розроблено алгоритм відновлення, ОЗО та підвищення експлуатаційних характеристик офсетних циліндрів i фарбових валів аркушевих офсетних друкарських машин. Запропонований алгоритм та запатентовані технологічні процеси дозволяють стверджувати про високу ефективність розробленого технологічного процесу. Його застосування дозволило збільшити адгезію гуми до тіла валу, підвищило зносостійкість під час друкування УФ-фарбами та дозволило скоротити періодичність планових відновлень валів у 1,6-1,9 разів.

4. Теоретично обґрунтовано та запропоновано математичну модель для розрахунку контактної площі поверхні, утвореної за допомогою повністю регулярного мікрорельєфу, на основі якої було побудовано алгоритм та ПЗ для керування технологічними процесами. Розроблено методику побудови математичних моделей та комплексного аналізу технологічних факторів, що дозволяє досліджувати такі складні процеси, як 
мікрозсуви офсетного гумовотканинного полотна та піддекельного матеріалу під час друкування на аркушевих та рулонних офсетних друкарських машинах, їх вплив на якість поліграфічної продукції, керувати процесами відновлення фарбових валів друкарської машини.

5. Досліджено та проаналізовано залежність зміни якості відтворення поліграфічної продукції до та після відновлення деталей, залежно від застосування різних систем контролю роботи обладнання. В результаті апробації та впро- вадження запропонованих рішень по технологічному забезпеченню експлуатаційних властивостей поліграфічного обладнання на основі системи контролю виробництва можна стверджувати, що найбільший ефект досягається при відновленні деталей на підприємстві, що працює на основі систем контролю. При цьому зменшення розтискування становитиме близько 29-30 \% порівняно із звичайним підприємством, також відбувається зменшення коефіцієнту браку до $4 \%$ та простоїв техніки через ремонтні роботи.

1. Petro Kyrychok, Anton Neskhozievskiy. Tear and Wear Processes in Printing Equipment. - Papers of the 42th conference of International Circle of Educational Institutes for Graphic Arts Technology and Management. - M. : ICEI. - 2010. - 80-81. 2. Бьюри С. Чтобы машина была в форме / С. Бьюри // Publish. - 2008. - № 3(106). - С. 44-51. 3. Белокрысенко В. Ф. Почему «разбиваются» печатне машины / В. Ф. Белокрысенко, И. П. Белоусова // КомпьюАрт. - 2007. - № 3 (123). - С. 46-50. 4. Несхозієвський А. В. Розробка системи контролю роботи друкарського обладнання / А. В. Несхозієвський // Технологія і техніка друкарства. - 2009. - № 3. С. 122-129. 5. Шевчук А. В. Система управління якістю поліграфічного комбінату «Україна» / А. В. Шевчук // Технологія і техніка друкарства : Зб. наук. пр. - К. : НТУУ «КПІ», 2004. - Вип. 1. - С. 24-33. 6. Несхозиевский А. В. Последнее предупреждение / А. В. Несхозиевский // PrintWeek. 2007. - № 13-14(66-67). - С. 30-32. 7. Молодык Н. В., Зенкин А. С. Восстановление деталей машин. Справочник. - М. : Машиностроение, 1989. $-480 \mathrm{c}$.

1. Petro Kyrychok, Anton Neskhozievskiy. Tear and Wear Processes in Printing Equipment. - Papers of the 42th conference of International Circle of Educational Institutes for Graphic Arts Technology and Management. - M. : ICEI. - 2010. - 80-81. 2. B'juri S. Chtoby mashina byla v forme / S. B'juri // Publish. - 2008. - № 3(106). - S. 44-51. 3. Belokrysenko V. F. Pochemu «razbivajutsja» pechatne mashiny / V. F. Belokrysenko, I. P. Belousova // Komp'juArt. - 2007. - № 3 (123). - S. 46-50. 4. Neskhoziievskyi A. V. Rozrobka systemy kontroliu roboty drukarskoho obladnannia / A. V. Neskhoziievskyi // Tekhnolohiia i tekhnika drukarstva. - 2009. - № 3. S. 122-129. 5. Shevchuk A. V. Systema upravlinnia yakistiu polihrafichnoho 
kombinatu «Ukraina» / A. V. Shevchuk // Tekhnolohiia i tekhnika drukarstva : Zb. nauk. pr. - K. : NTUU «KPI», 2004. - Vyp. 1. - S. 24-33. 6. Neshozievskij A. V. Poslednee preduprezhdenie / A. V. Neshozievskij // PrintWeek. - 2007. - № 13-14(66-67). - C. 30-32. 7. Molodyk N. V., Zenkin A. S. Vosstanovlenie detalej mashin. Spravochnik. - M. : Mashinostroenie, 1989. — $480 \mathrm{~s}$.

Рецензент - В. П. Шерстюк, д.х.н., професор, НТУУ «КП।»

Надійшла до редакції 18.03.13 